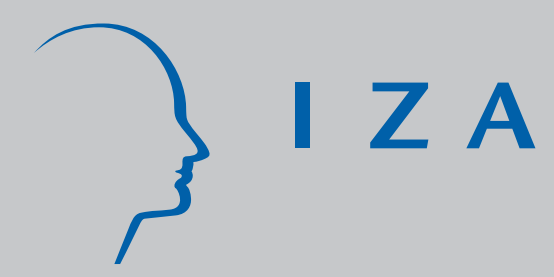

IZADP No. 1968

Does the Quality of Industrial Relations Matter for the Macro Economy? A Cross-Country Analysis Using Strikes Data

J ohn T. Addison

Paulino Teixeira

February 2006 


\title{
Does the Quality of Industrial Relations Matter for the Macro Economy? A Cross-Country Analysis Using Strikes Data
}

\author{
John T. Addison \\ University of South Carolina, \\ Universidade de Coimbra/GEMF and IZA Bonn \\ Paulino Teixeira \\ Universidade de Coimbra and GEMF
}

Discussion Paper No. 1968

February 2006

\author{
IZA \\ P.O. Box 7240 \\ 53072 Bonn \\ Germany
}

Phone: +49-228-3894-0

Fax: +49-228-3894-180

Email: iza@iza.org

\begin{abstract}
Any opinions expressed here are those of the author(s) and not those of the institute. Research disseminated by IZA may include views on policy, but the institute itself takes no institutional policy positions.

The Institute for the Study of Labor (IZA) in Bonn is a local and virtual international research center and a place of communication between science, politics and business. IZA is an independent nonprofit company supported by Deutsche Post World Net. The center is associated with the University of Bonn and offers a stimulating research environment through its research networks, research support, and visitors and doctoral programs. IZA engages in (i) original and internationally competitive research in all fields of labor economics, (ii) development of policy concepts, and (iii) dissemination of research results and concepts to the interested public.
\end{abstract}

IZA Discussion Papers often represent preliminary work and are circulated to encourage discussion. Citation of such a paper should account for its provisional character. A revised version may be available directly from the author. 
IZA Discussion Paper No. 1968

February 2006

\section{ABSTRACT}

\section{Does the Quality of Industrial Relations Matter for the Macro Economy? A Cross-Country Analysis Using Strikes Data}

Using international data, we investigate whether the quality of industrial relations matters for the macro economy. We measure industrial relations inversely by strikes - which proxy we cross-check with an industrial relations reputation indicator - and our macro performance outcome is the unemployment rate. Independent of the role of other institutions, good industrial relations do seem to matter: greater strike volume is associated with higher unemployment. Holding country effects constant, however, the sign of the variable is reversed. This fixed-effects result likely picks up a direct effect of strikes, namely, their tendency to rise when striking becomes more attractive to the union.

JEL Classification: E24, J52, J53, J64, J65

Keywords: strike rate/volume, quality of labor relations, labor market institutions, unemployment

Corresponding author:

John T. Addison

Department of Economics

Moore School of Business

University of South Carolina

1705 College Street

Columbia, SC 29208

USA

Email: ecceaddi@moore.sc.edu

\footnotetext{
This paper was first presented at the University of Nürnberg-Erlangen under the auspices of the Bavarian Postgraduate Program in Economics. The authors are indebted to seminar participants for their helpful suggestions.
} 
"What might lead to different speeds of learning and adjustment by unions? Bayesian learning points to differences in the tightness of priors, and the informativeness of signals. More generally, it points to differences in ideology and in the quality of industrial relations: The more unions and firms share a common economic model, or the more they discuss the economic implications of different shocks, the faster learning and adjustment is likely to be." (Blanchard and Philippon, 2004, p. 11)

The argument that the quality of labor relations matters for economic performance is widely encountered in the industrial relations literature even if it has proven difficult to sustain in practice. The best example is of course the ambiguous role of workplace governance on workplace performance. For example, using British WERS data, Fernie and Metcalf (1995) found that authoritarian workplaces performed better on some dimensions of firm performance than did the archetypal employee involvement workplace, while Wood and de Menezes (1998) reported that workplaces assessed to have high high commitment management were not more effective than their counterparts with medium-low, low-medium, and low levels of high commitment management along seven dimensions of work performance. Recent British work on social partnership agreements paints a somewhat more optimistic picture, although this may be premature (see, respectively, Metcalf, 2003; Kelly, 2004).

For its part, the U.S. literature on employee involvement/high performance work practices also presents mixed results on the effects of labor management cooperation (for a review, see Addison, 2005). On the other hand, very recent analyses of strikes - long treated as an outcome indicator rather than an input - are offering interesting insights into the quality of industrial relations at the workplace and its effects on productivity (and practices such as TQM) and output quality (see Kleiner et al., 2002; Krueger and Mas, 2004). ${ }^{1}$ 
There has been almost no attempt to factor the industrial relations climate into the determination of macro outcomes, even if industrial relations processes have not been neglected in that literature. Thus, the degree of centralization in collective bargaining and, latterly, the extent of coordination of the bargaining parties/process have recently been entered alongside (the monopoly arguments of) union coverage and union density as determinants of unemployment and employment (see section 2). In the most recent development, however, a measure of the climate of labor relations has been added to the growing number of collective bargaining variables in macro analysis.

The new argument is a measure of strikes, a negative proxy for the "quality of labor relations.” Specifically, Blanchard and Philippon (2004) argue that, in countries where wages are largely determined by collective bargaining, the effects on unemployment of changes in the economic environment will depend in large part on the speed of learning of unions. This speed of learning is in turn seen as a reflection of the quality of the dialogue between the two sides, or the quality of industrial relations. The roles of the dialogue and labor market institutions are modeled principally in conjunction with economic shocks.

The authors' formal model illustrates how the effect of shocks on unemployment depends largely on whether and how fast they are perceived by unions. The model assumes an economy-wide union acting as a monopoly and seeking to maximize the wage bill period by period subject to a perceived labor demand. The actual labor demand is derived on the basis of a specific aggregate production function (incorporating Harrodneutral technological change) and a particular supply of capital function. The key parameters of the demand function are productivity, the response of the supply of capital 
to net profit, and the firm's user cost of capital. (As practical matter, the last two parameters are held constant.) Accordingly, the union chooses the wage unilaterally on the basis of its perceptions of these parameters. The level of employment is then set by firms on the basis of the actual demand schedule. If the union's perceptions are correct, it follows that the economy will proceed along a balanced growth path where capital, output, and real wages grow in line with productivity and employment holds constant. Now, imposing a negative shock to productivity growth, employment will only remain constant if union perceptions adjust fully and wages adjust appropriately. If perceptions do not fully adjust, perceived productivity will exceed actual productivity and employment will be lower until the expected productivity converges back to actual productivity.

Assuming stochastic productivity - where actual productivity equals underlying productivity plus white noise and where underlying productivity growth can either be positive or zero - unions will learn and adjust wages at a rate according to the tightness of their prior and the standard deviation of the transitory component. The authors simulate one such path of wage (and hence employment) adjustment for two such values and an assumed fall in underlying total factor productivity growth from 1 percent to 0 percent. For the parameters chosen it takes around 7 years for employment to return to its pre-shock value.

It follows that the speed of union learning and adjustment is crucial. The authors link this speed to the quality of the dialogue that unions have with firms or, equivalently, with the quality of labor relations. As an example of this they cite the case of the evolution of unemployment in the Netherlands since the Wassenaar Accord of the early 
1980s, the so-called Dutch miracle (see Nickell and van Ours, 2000). Much more important than this 'case study,' however, is the authors' empirical analysis of unemployment in 18 OECD nations over four decades of data, 1965-2003. The authors proxy the quality of industrial relations by (a) strike intensity from 1960 to 1967, as measured by the maximum of days lost and workers involved, both normalized by the cross country standard deviations, ${ }^{2}$ and (b) a direct measure based on the responses of managers in large firms in 1999 to a World Economic Forum question seeking to determine the extent to which labor relations in their firms were "cooperative," on a scale from 1 to 7 (mean country response). They also use days lost per employee and workers involved in strikes in the 1960s to instrument for the 1999 survey measure. ${ }^{3}$

We summarize their full model below after having discussed the macro literature in which that model is located. We note here the results of the authors' initial analysis. Simple bivariate regressions of unemployment on the three (fixed) measures of the quality of industrial relations for each of the four decades (1965-74, 1975-84, 1885-94, and 1995-2003) suggest that the quality of industrial relations does matter. Specifically, countries with a one standard deviation better quality had about 1 percent less unemployment than the average country in the first decade rising to 2-2.5 percent less in the last two decades. If this result is robust the authors have uncovered an important additional influence of industrial relations - its quality and not just its structure - on a key macro indicator.

In investigating these issues, the plan of the present treatment is as follows. In the next section, we present a brief background sketch of the particular macro literature in which the new industrial relations arguments are embedded and outline the more detailed 
findings of Blanchard and Philippon. We next introduce the empirical models and the data used in this inquiry, before presenting our empirical results. Points of agreement and disagreement with Blanchard and Philippon are adumbrated in a concluding interpretative section.

\section{Background Literature}

The underlying macro-applied literature is the economics of employment protection. The starting point is Lazear's (1990) parsimonious representation of the determinants of unemployment (as well as three other labor market aggregates - the employment-population ratio, the labor force participation rate, and average hours worked - all using the same arguments). Lazear's key independent variable is a timevarying measure of severance pay; specifically, the amount of statutory severance pay due to a blue-collar worker with 10 years of service dismissed for reasons unconnected with his or her behavior. The only other independent variables are a quadratic in time, the growth in per capita GDP (to accommodate the notion that a growing economy vitiates at least in part the probabilistic costs of severance pay), and a demographic control (the population of working age). Lazear reports that the more generous the severance pay entitlement, the greater is unemployment. These adverse effects are found to be especially serious in the cases of France, Portugal, and Italy.

Following Lazear, the literature developed in two main directions. First, there was search for a more inclusive measure of employment protection than just severance pay. This culminated in the well-known OECD (1994) rankings of the 'strictness' of employment protection legislation for regular contracts and fixed-term contracts (and 
their composite). The regular contracts component included not only months of severance pay for no-fault dismissals but also procedural delays and other complications (such as prior authorization) before notice could be activated, as well as the perceived difficulty of dismissal as indexed by the legal conditions defining 'fair' and 'unfair' dismissals (trial periods, compensation payable, and extent of reinstatement). The fixed-term contract component included the objective grounds for entering into such employment relationships (and permitted derogations), together with the maximum number of successive contracts and their maximum cumulated duration. Rankings for 16 countries were derived, pertaining to the "the late 1980s," so that the price of inclusiveness was a single data point rather than the time-varying measure of Lazear. The OECD (1999) subsequently revised its overall and component measures of employment protection for “the late 1990s," thus providing researchers with two data points - and for a modestly enlarged sample of 19 countries. $^{4}$

The second development was the inclusion of a wider range of regressors than considered by Lazear, omitted variables that might either bias the coefficient estimate for employment protection (by virtue of their correlation with that measure and the dependent variable) or which might otherwise amplify or reduce the effect of policy on economic aggregates (and hence reveal more than the simple 'average effect' of employment protection). Chief among these variables have been union arguments, aspects of the unemployment insurance system, the tax wedge, and active labor market policies (and, latterly, the degree of product market regulation).

Collective bargaining arguments such as union density and union coverage have typically been included on the grounds that they are directly associated with pay, and 
thence unemployment. Additional arguments based on centralization or coordination have a very different pedigree. Initially, it was argued that a more centralized bargaining framework should lead to improved employment outcomes vis-à-vis a less centralized (but not totally decentralized) system because the disemployment and price/tax consequences of excessive wage increases would be more transparent, leading unions to take account of the effects of wage increases on all workers (Calmfors and Driffill, 1988). The result is a humped or inverse U-shaped relation between wage restraint and centralization - with full decentralization and centralization yielding equivalent outcomes, and sector-level bargaining (in association with high union density) producing the worst of all worlds. More recently, researchers have increasingly relied on the notion of coordination, ostensibly because the underlying model relies more on behavior than the fact of centralization (e.g. Soskice, 1990; Nickell, 1997; Nickell and Layard, 1999). ${ }^{5}$ The spirit of the literature is nicely captured in Nickell's (1997, p. 68) dictum: “[U]nions are bad for jobs, but these bad effects can be nullified if both the unions and the employers can coordinate their wage bargaining activities.”

Theory suggests that unemployment benefits clearly belong in employment equations irrespective of omitted variable bias (e.g. where systematic employment protection substitutes for unemployment insurance) or any moderating or amplifying effect benefits might may have on employment protection. Thus, more generous unemployment benefits lower the opportunity cost of unemployment and elevate wage pressure at the same time that they subsidize search. The upshot is higher equilibrium unemployment because of lengthened jobless duration. Ideally, the unemployment benefits measure should reflect the generosity of the UI system, including the maximum 
duration of unemployment insurance benefits and any prolongation under separate unemployment assistance benefits. Practically, researchers have been able to draw on a cross-country summary measure provided by the OECD, based on an average of gross replacement rates for individuals with two earnings levels, three family situations, and three duration categories of unemployment (for odd numbered years). ${ }^{6}$

Operating alongside unemployment benefits are measures that may have exactly the opposite effect on unemployment, namely, active labor market programs, operating directly on unemployment by improving search efficiency and indirectly by reducing wage pressure. Equally, they may not, most obviously perhaps where they signal future accommodation by the authorities to inflationary wage demands. Expenditures on active labor market policies are typically expressed as a percentage of GDP or as expenditures per unemployed individual relative to GDP per capita. ${ }^{7}$

The final labor market institution identified here is the tax wedge, namely the gap between the gross labor costs to employers and the consumption wage paid to labor (i.e. the wage after deduction of direct and indirect taxes). ${ }^{8}$ This 'institution' may have little effect on unemployment, with the incidence falling mainly upon wages. On the other hand, if markets are imperfect there may be no offsetting wage cuts, while formal and implicit wage floors (set respectively by minimum wage legislation and social welfare provisions) will make labor taxes harmful to low-productivity workers.

If the upshot of these post-Lazear innovations is mixed with respect to the impact of employment protection on unemployment (see Addison and Teixeira, 2003, pp. 105107), there is some agreement on the effect of the structure of collective bargaining and several of the other arguments. Thus, most studies report that increased coordination is 
associated with lower unemployment, either independently or in conjunction with employment protection and adverse shocks (Scarpetta, 1996; Nickell, 1997; Elmeskov et al., 1998; Nickell and Layard, 1999; OECD, 1999; Blanchard and Wolfers, 2000). ${ }^{9}$ By the same token, greater union coverage and higher union density are often associated with greater unemployment, although the relationships are often weak. Most of the other arguments noted above have the expected effects on unemployment.

Blanchard and Philippon (2004) fit their 'quality of labor relations' model to data on joblessness for 18 countries, 1965-2003, using four decade-long averages of unemployment data. Their preferred specification allows the impact of a common (unobservable) aggregate shock to depend on a linear combination of nine institutions. In addition to the state of labor relations in 1999, instrumented by strikes in the 1960s, the institutions include all those mentioned above (as formally identified in Blanchard and Wolfers, 2000). They comprise fixed measures of employment protection, the UI replacement rate, the maximum duration of UI benefits, the tax wedge, active labor market policies, and the three collective bargaining measures (union coverage/density and the degree of coordination in collective bargaining). To repeat, in each case the measures are interacted with the time dummy variables since the maintained hypothesis is that the main route through which institutions impact employment is how well they mediate economic shocks. ${ }^{10}$

Blanchard and Philippon find that cooperation in industrial relations in an equation containing just this argument and the three decade-long year dummies is negative and well determined; alternatively put, strikes are positively associated with unemployment. When the other eight institutional regressors are added to the equation, 
the point estimate of cooperation in industrial relations falls somewhat in absolute magnitude but remains highly significant. No less interesting is the fact that the statistically significant and opposing effects of coordination and union density on unemployment - the former lowering joblessness and the latter elevating it - remain well determined.

Blanchard and Philippon (2004, p. 17) conclude that the quality of industrial relations matters and that the influence is material. If this result proves robust, the authors have uncovered an important additional influence of industrial relations - its quality and not just its structure - on a key macro indicator in a framework that yields results for other arguments that are consistent with earlier research.

\section{The Model and Data}

Let us denote the key labor market performance indicator - unemployment - by $y$. Assuming that countries in the dataset are observed at different points in time, unemployment in country $i$ in period $t$ is then given by $y_{i t}$. Further assume that in each country, at each data point, we observe a set of country-specific labor market institutions, $X_{i t j}, j=1,2, \ldots, k ; i=1,2, \ldots, N$; and $t=1,2, \ldots, T$.

Within this panel data structure, several modelling strategies can be followed. One route is of course to use the full length of each country's time-series at annual frequencies. Given serious data limitations, especially in gathering meaningful annual data on labor market institutions for a sufficiently representative set of countries, we cannot pursue this approach. But an interest in the long-term effects of institutions would anyway involve the use of longer time intervals than a year - to avoid contamination 
from cyclical fluctuations - and so even if we had annual data we might seek to average it over intervals of five years or a decade.

Measuring how institutions impact labor market outcomes is necessarily more subtle. It has typically been addressed in one of two alternative ways. First, it has been assumed that the role of any given labor market institution can be captured independently (or in interaction with other institutions) (e.g. Nickell, 1997; Belot and van Ours, 2004). Second, institutions may be depicted as interacting with shocks, either ameliorating or aggravating the impact of adverse exogenous shocks (Blanchard and Wolfers, 2000). In this latter case, the impact of a shock can be modelled as a function of given set of institutions, yielding a nonlinear model in the parameters; whereas the former model is linear by definition and can be estimated using standard OLS techniques. Within these two approaches, the present paper assembles a new set of time-varying institutions, while inserting a new institution: the quality of labor relations.

Formally, let us assume the following general empirical model ${ }^{11}$

$$
y_{i t}=X_{i t} \beta+c_{i}+u_{i t},
$$

where $X_{i t}$ includes all the relevant labor market institutional measures, $c_{i}$ is the crosssection unobserved effect (or unobserved country heterogeneity), and $u_{i t}$ is the idiosyncratic error, or disturbance, term, with $\mathrm{E}\left(u_{t} \mid X_{t}, c\right)=0$. For convenience, further assume that $X_{i t}$ contains both time-invariant and time-varying variables, in addition to time (calendar) dummies. Interaction terms between institutions and between time and institutions can also be added to the specification. This model is linear in the parameters and the evaluation exercise will consist in obtaining an estimate of $\beta$. Obvious candidates are, respectively, the pooled OLS, fixed-effects, and random-effects estimators $\hat{\beta}_{\text {OLS }}$, 
$\hat{\beta}_{F E}$, and $\hat{\beta}_{R E}$. In the spirit of Blanchard and Philippon (2004), if we for the moment neglect the fixed effects case by noting that the data are thin (occasioned by a short sample period - a maximum of six intervals - and modest changes in institutions through time), the main option is random effects (in the linear version of model (1)). This assumes that all cross-section heterogeneity will be picked up by the array of institutions, and that the unobserved effect $c_{i}$ is uncorrelated with the observed $j$ labor market institutions. However, results from fitting the standard pooled OLS model will be used to provide a set of initial estimates. ${ }^{12}$ In this context, and again in the spirit of Blanchard and Philippon, we will also report results from a simpler exercise regressing the outcome variable (unemployment) on our indicator(s) of the quality of industrial relations in separate cross sections for each of the 5-year intervals making up our sample period.

Within the framework of model (1), the course of unemployment $y_{i t}$ is explained by either changes in the $X_{j}$ institutions or changes in common across-country shocks (proxied by time dummies). In principle, within-country changes in institutions are not well suited to explain differences in outcomes across time because of the persistence of institutions. In turn, common across-country shocks cannot of course explain differences between countries. Interactions between shocks and institutions thus emerge as the natural candidate to explain differences in labor market performance. The possibility that 'unfavorable' institutions only reveal their true nature under adverse states of nature requires however a different modelling strategy, which can be translated into the following model (after Blanchard and Philippon, 2004, p. 15)

$$
y_{i t}=\left(\theta_{1 t}+\theta_{2} d 2_{t}+\ldots+\theta_{T} d T_{t}\right)\left(1+\sum_{j=1}^{k} X_{i t j} b_{j}\right)+u_{i t},
$$


where the variables $d 2_{t}, \ldots, d T_{t}$ denote time period dummies so that $d s_{t}=1$ if $s=t$. (These variables are proxies for the unobserved common across-country shocks.) As in equation (1), the variables $X_{j}$ can represent both time-invariant and time-varying institutions. Clearly, this model does not include any country dummies; nor does it permit the estimation of any 'autonomous' impact of institution $j$ on $y_{i t}$. Rather, by specifying the impact of the time-specific shocks, $d s_{t}, s=1, . ., T$, as a function of a linear combination of institutions, $\sum_{j} X_{i t j} b_{j}$, the model concentrates fully on whether, say, a negative shock (one that increases unemployment) translates into more unemployment due the presence of institution $j$. Under model (2), therefore, if $b_{j}$ is positive and a given economy is hit by an adverse shock, then institution $j$ 'creates' more unemployment. Correspondingly, if $b_{j}$ is negative, then institution $j$ insulates the economy from any adverse shock, or at least softens its impact. The required technique to estimate the parameters of the model is of course nonlinear. ${ }^{13}$

Subject to the caveats entered earlier, and as a final exercise, we will also examine models (1) and (2) in a fixed-effects framework, which for model (2) - the NLS case amounts to simply adding country dummies. Further limitations of the fixed-effects estimator will also be noted.

Our database contains six time-varying institutional indicators (and two alternative measures of the quality of labor relations) for 19 OECD countries: Australia, Austria, Belgium, Denmark, Finland, France, Germany, Ireland, Italy, Japan, the Netherlands, New Zealand, Norway, Portugal, Spain, Sweden, Switzerland, the United Kingdom, and the United States. The conventional labor market institutional variables are severance pay, the unemployment insurance replacement rate, union density, union 
coverage, union and employer coordination, and the tax wedge. (The absence of active labor market policies and benefit duration from this list is explained by the lack of time series information for these arguments.) The manner in which we obtain six 5-year averages for each variable is outlined in Appendix Table 1. Further, as in Blanchard and Philippon (2004), the variables are defined in such a way that an increase in a particular measure is expected to increase unemployment, which means in particular that the coordination measure is multiplied by -1 . Table 1 provides the corresponding country means, with the sample period being divided into six 5-year periods from 1970-99 (namely, 1970-74, 1975-79, 1980-84, 1985-99, 1990-1994, and 1995-99).

(Table 1 near here)

We will use two proxies for the quality of labor relations. Our main measure is the strike rate (or 'strike volume' as it is sometimes known), namely, the number of days not worked per thousand paid employees. This ratio is based on revisions to the raw International Labor Office series on strikes (contained in the Yearbook of Labor Statistics, Tables 9A-D) kindly made available by Claus Schnabel of the University of Erlangen-Nürnberg. The data is available on an annual basis and is grouped into 5-year averages. Our second proxy is a direct, survey-based indicator of the quality of industrial relations. It is taken from the World Competitiveness Yearbook 2000, published by the International Institute for Management Development (IMD), Switzerland. In the IMD survey, national respondents are asked to rate the state of industrial relations on a scale ranging from 1 ("hostile") to 10 ("productive"). Unlike the indirect measure of the quality of industrial relations, this indicator is solely time invariant - since publication of the IMD index started only in 1989. 
(Figure 1 near here)

Figure 1 charts the course of the strike rate/volume over time for all countries in

the sample, again for 5-year intervals. Although there is a considerable decrease in strike activity over time, it is also the case that countries show stability in their relative positions. Taking all possible combinations between 5-year periods (15 in total), the Spearman rank correlation coefficients always exceed 0.8, other than for those involving the last five-year interval, where the estimates fall in 0.5-0.7 range.

\section{Findings}

Estimates of the basic Blanchard-Philippon model containing just the quality of labor relations variables is given in Table 2 for six separate cross sections of the data. In the first row of the table, the strikes measure differs over each 5-year period, unlike in Blanchard and Philippon, where it remains fixed (at its level for 1960-67). In the second row, however, the direct reputational (i.e. survey) measure is fixed at its 2000 reported value throughout, so that only the unemployment rate changes. The same is true for the instrumented for the degree of cooperation in industrial relations in the last row. To control for potential reverse causality - the course of unemployment over the period perhaps influencing the perceptions of survey respondents as to the quality of industrial relations - we also instrumented the IMD index by the observed strike rate/volume in the 70s, 80s, and early 90s. (Use of the strike rate in the 70s as an instrument, as well average strike volume over the sample period, produced no material change in the results.)

(Table 2 near here) 
Our findings accord with those reported by Blanchard and Philippon (2005, Table 1); specifically, greater strike volume is associated with heightened unemployment, while the direct survey measure(s) of the quality of labor relations is associated with reduced joblessness. As can be seen, most of the coefficient estimates are well determined, with the main exception of that for the indirect measure in the most recent 5-year interval. We note that the same broad findings hold when we ran separate regressions by decade - as do Blanchard and Phillipon - using two clouds of data for each decade. ${ }^{14}$

(Table 3 near here)

Table 3 gives results from using all our labor market indicators for the full sample period, 1970-99. Separate results are given for the strikes proxy and for the direct measure of the quality of industrial relations. Note that each measure is time invariant, strikes now being set at their average value over the six 5-year periods (although this restriction will subsequently be relaxed). All other labor market institutions are timevarying. The general finding is that Blanchard and Philippon's conjectures again hold up rather well. Thus for the pooled OLS estimates it can be seen that the strike rate is positively associated with unemployment and the survey measure (of the degree of cooperation in industrial relations) is negatively associated with unemployment. The coefficient estimates for both arguments are well determined. Of the other institutional influences, the effects of higher replacement rates and greater coordination in collective bargaining are as expected - recall that the coordination score has been multiplied by -1 and the coefficient estimates are statistically significant at conventional levels. But although the effect of higher levels of union coverage (one of the two monopoly union 
arguments) is of the expected sign, this is not the case for the other monopoly union measure.

The estimates reported in columns (1) through (3) of Table 3 assume away unobserved cross-country heterogeneity. Since application of the standard Breusch-Pagan test rejected the null of constant variance of the error term (homoskedasticity), we reestimated the base model using random effects. The GLS estimates provided in the next three columns of the table again support Blanchard and Philippon's conjectures as to the impact of good industrial relations on unemployment. Again the coefficients on the strike and reputation measures are of the expected sign and remain well determined. The performance of the labor-market institutions proper also improves somewhat, although the perverse effects of union density persist.

The estimates in the last three columns of Table 3 return us to Blanchard and Philippon's preferred specification, conforming to our equation (2). As can be seen, the effect of the labor market institutions proper further strengthens. And again the two measures of the industrial relations climate operate in the hypothesized manner, with strikes adversely impacting the effect of negative shocks and cooperation in industrial relations ameliorating them.

\section{(Table 4 near here)}

Table 4 repeats the regressions in columns (2), (5) and (8) of Table 3, substituting the 5-year, time-varying strikes measure for the measure in which strikes are averaged over the six 5-year periods. The coefficient estimate for strike rate/volume is no longer statistically significant in the random effects GLS specification but remains well 
determined in Blanchard and Philippon's preferred specification (i.e. the NLS estimates in column (3) of the table).

\section{(Table 5 near here)}

Thus far, our results offer not unimpressive support for the notion that good industrial relations - proxied inversely by strike volume or directly via a reputation measure of the degree of cooperation in industrial relations - do matter in influencing unemployment, either independently or taken in conjunction with economic shocks. In Table 5, we investigate whether the above relationships still hold when we control for country effects. Blanchard and Philippon do not consider fixed effects specifications because of the fixed nature of their proxy(ies) for the state of labor relations. ${ }^{15}$ In the first column of the table, we provide fixed effects estimates of the basic model, and in second column we add country dummies to the (NLS) specification in which institutions interact with shocks. The results are dramatic. In particular, although the strike rate remains highly statistically significant its sign is reversed: strike volume is now negatively associated with unemployment. Also the performance of the institutional variables deteriorates vis-à-vis the results in Tables 3 and 4.

Although this reversal of the Blanchard-Philippon dictum is at first sight troubling, we think the change in sign of the coefficient of the strikes variable may be explained in one of two ways. First, we would argue that use of a time-varying measure of strikes may pick up cyclical influences necessarily ignored in Blanchard and Philippon's treatment but long emphasized in the micro strikes literature. Thus, for example, in Ashenfelter and Johnson's (1969) early model of strikes the higher is the union's minimum acceptable wage increase (and the higher its rate of concession), the 
more likely are strikes. Ashenfelter and Johnson conjecture that the union's minimum acceptable wage increase is a negative function of the unemployment rate. Although there are problems with this one-sided political model of strikes, the evidence continues to suggest that that strike frequency is procyclical, consistent with the findings in Table 5 (e.g. Hirsch and Addison, 1987; Cramton and Tracy, 2003). The caveat is that the strikes measure in the present study is a conflation of frequency and duration, and it may be the case that strike duration is countercyclical - although contrary evidence, at least for large strikes, is provided by Harrison and Stewart (1993). If strike volume is indeed procyclical this might explain the negative association between this time-varying measure and unemployment. Equally, by the same token, it can play no part in an empirical application in which strike volume averaged over 1960-67 is used to predict unemployment in subsequent decades and indeed the quality of industrial relations in the late 1990s.

Measurement error in the RHS variables may, however, call into question these estimates and our interpretation of them. Hauk and Wacziarg (2004) have recently argued that, in such circumstances, the between effects (BE) estimator - that is, the OLS estimator applied to a single-cross-section of variables averaged over time may outperform the fixed-effects estimator by averaging out measurement errors. In recognition of this possibility, the final column in Table 3 contains results for the $\mathrm{BE}$ estimator. The results for the strikes variable are striking: its coefficient estimate rate changes in sign, and is once again positive and well determined. All other variables with the exception of the union density covariate have the expected signs. 


\section{Conclusions}

In an important departure, it has recently been argued by Blanchard and Philippon (2004) that what is good for industrial relations might after all be good for performance, this time at the macro level. Suggesting that the quality of industrial relations might be (inversely) proxied by strikes, these authors were able to find strong support for their claim that 'quality' matters in unemployment determination. For example, one of their findings is that countries with one standard deviation better quality had enjoyed 2 to 2.5 percent lower unemployment over the course of the last two decades, ceteris paribus. Moreover, they reported that this quality effect operated over and above the benefits conveyed by greater union and employer coordination in collective bargaining.

In the present treatment, we further investigated the quality issue. Our innovations included the use of annual strike data (and strike data averaged over the sample period rather than being set at beginning-of-period values or indeed earlier), the derivation of a direct moment-in-time indicator of labor relations supported by different survey data, and the construction and deployment of time-varying institutional variables. The BlanchardPhilippon hypothesis was found to hold up really rather well. Higher strike volume averaged over the sample period and greater cooperation in industrial relations at end period were found to be related to the macro performance indicator in the manner these authors hypothesized. Allowing strike volume to vary through time, and not just institutional innovations, weakened but did not overturn the Blanchard-Philippon result for their preferred model.

The fly in the ointment was occasioned by the within estimator. That is to say, when we introduced country dummies, the sign of the relation between strikes and 
unemployment abruptly reversed itself. However, drawing on the micro strikes literature, we argued that this result likely reflected the dominance of cyclical over any longer-term influences. Nevertheless this sensitivity requires further examination than provided here because there are enough hints in national experience to suggest that the quality of industrial relations can vary materially, and because the focus on the unemployment outcome might be unduly restrictive. The contribution of measurement error is another issue. But in the interstices we have been able to adduce real support for the recherché notion of the potential importance of trust between the 'two sides of industry,' namely, that countries with better industrial relations may be able to limit the rise in unemployment and recover faster. 


\section{Endnotes}

1. Strikes are of course not the only measure of industrial relations quality/performance. Another is grievances. Two early studies of General Motors plants and of ten paper mills found that the number of grievances was inversely related to productivity (see, respectively, Katz et al., 1983; Ichniowski, 1984). A review of the earlier literature on the relationship between labor-management conflict and firm performance, is provided by Belman (1992).

2. The use of the max specification is justified on the grounds that both measures are likely to be lower bounds on strike activity.

3. The use of IV analysis is justified on the grounds that reverse causality attaches to this more direct measure of industrial relations quality: the evolution of employment might condition attitudes as to the quality of industrial relations.

4. Other indicators of employment protection are available from surveys of employers. One such survey is the World Competitiveness Report (WCR), utilized below. This covers some 21 countries and inquires of top management a large number of questions concerning national competitiveness. An overall index of competitiveness is provided and is the weighted linear sum of the components. Research has tended to focus on responses to individual questions in the WCR concerning the market friendliness of economic institutions, as indexed by the flexibility of the enterprise to adjust job security and compensation standards to economic realities (e.g. Di Tella and MacCulloch, 1999).

5. Other analysts have deployed both centralization and coordination regressors (see Scarpetta, 1996; Elmeskov et al., 1998; OECD, 1999).

6. There is unfortunately no parallel time series information on the maximum duration of unemployment benefits.

7. Since spending on active measures is endogenous it is conventional to characterize the variable as a fixed effect, instrumenting it by the average spending over the sample period.

8. Additional variables used in the literature include cyclical variables (proxied by the inflation rate or the output gap), barriers to geographic mobility (proxied by extent of home ownership), the stance of macroeconomic policy, controls for the terms of trade and real interest rates, and product market competition. Product market regulation has 
been used as a regressor in studies of employment rather than unemployment (e.g. Nicoletti and Scarpetta, 2001). And most recently attention has shifted to the issue of fundamental rather than proximate causation and to the endogeneity of labor market institutions (e.g. Botero et al., 2004).

9. For a treatment that downplays the role of direct effects and elevates the role of combinations of institutions (and policies), see Belot and van Ours' (2004) analysis of unemployment (and nonemployment) in 19 OECD countries, 1960-99. Among other relationships, the authors report a positive interaction between union density and centralization and a negative interaction between employment protection and centralization.

10. Note that all measures of labor market institutions are defined such that an increase in the measure is expected to increase the effect of an adverse shock, requiring in the case of active labor market policies and degree of coordination that the measures are multiplied by -1 .

11. This general specification can be designated as an Unobserved Effects Model (UEM) (Wooldridge, 2002, Chapter 10).

12. Pooled OLS assumes away unobserved effects $c_{i}$. Under the assumption that $\mathrm{E}\left(X^{\prime}{ }_{i t} c_{i}\right)$ $=0$, the pooled OLS estimator is consistent but the error term will be serially correlated due to the presence of the time-invariant component $c_{i}$. Inference based on pooled OLS will then require robust standard errors. The random effects implementation of model (1) assumes $\mathrm{E}\left(X^{\prime}{ }_{i t} c_{i}\right)=0$ and exploits the serial correlation in the composite error, $e_{i t}=c_{i}+u_{i t}$, in a generalized least squares (GLS) framework.

13. From model (2) above, the partial effect of $X_{j}$ on $y$ is given by: $E\left(\frac{\partial y}{\partial X_{j}} \mid X, c\right)=\theta_{s} * b_{j}$, for a given year $s, s=1,2, \ldots, T$.

14. The point estimate of the strikes measure was strongly statistically significant in the 1970s and 1990s, although not the 1980s, while the coefficients for the direct measures were well determined throughout.

15. In particular, their strike measure is based on beginning of period values for 1960-67 on the grounds that it precedes the rise in unemployment they are seeking to explain. They add (Blanchard and Philippon, 2004, p. 11) that "the reason for stopping in 1967, 
rather than, say, 1970, is that, in the late 1970s, many European countries, especially France, Germany, and Italy, were affected by social and political unrest, for reasons largely unrelated to the quality of industrial relations." 


\section{References}

Addison, John T. 2005. "The Determinants of Firm Performance: Unions, Works Councils, and Employee Involvement/High Performance Work Practices.” Scottish Journal of Political Economy 52 (July): 406-450.

Addison, John T. and Paulino Teixeira. 2003. "The Economics of Employment Protection.” Journal of Labor Research 24 (Winter): 85-129.

Ashenfelter, Orley and George E. Johnson. 1969. "Bargaining Theory, Trade Unions, and Industrial Strike Activity.” American Economic Review 59 (March): 35-49.

Blanchard, Olivier and Thomas Philippon. 2004. “The Quality of Labor Relations and Unemployment.” National Bureau of Economic Research Working Paper 10590, June.

Blanchard, Olivier and Justin Wolfers. 2000. "The Role of Institutions in the Rise of European Unemployment: The Aggregate Evidence.” Economic Journal 110 (March): C1-C33.

Belot, Michèle and Jan C. van Ours. 2004. "Does the Recent Success of Some OECD Countries in Lowering Their Unemployment Rates Lie in the Clever Design of Their Labor Market Reforms?” Oxford Economic Papers 56 (October): 621-642.

Belman, Dale. 1992. “Unions, the Quality of Industrial Relations and Firm Performance.” In Unions and Economic Competitiveness, edited by Lawrence R. Mishel and Paula B. Voos. Armonk, N.Y.: M.E. Sharpe, pp. 41-107.

Botero, Juan C., Simeon Djankov, Raphael La Porta, and Florencio C. Lopez-de-Silanes and Andrei Shleifer. 2004. “The Regulation of Labor.” Quarterly Journal of Economics 119 (November): 1339-1382. 
Calmfors, Lars and John Driffill. 1988. "Centralization of Wage Bargaining and Macroeconomic Performance.” Economic Policy 3 (April): 13-61.

Cramton, Peter and Joseph S. Tracy. 2003. "Unions, Bargaining and Strikes." In International Handbook of Trade Unions, edited by John T. Addison and Claus Schnabel. Cheltenham, England, and Northampton, MA: Edward Elgar, pp. 86-117.

Di Tella, Rafael and Robert MacCulloch. 1999. "The Consequences of Labor Market Flexibility: Panel Evidence Based on Survey Data.” Unpublished paper, Harvard Business School, April.

Elmeskov, Jørgen, John P. Martin, and Stefano Scarpetta. 1998. "Key Lessons for Labor Market Reforms: Evidence from OECD Countries’ Experiences.” Swedish Economic Policy Review 5: 207-252.

Fernie, Sue and David Metcalf. 1995. "Participation, Contingent Pay, Representation and Workplace Performance: Evidence from Great Britain.” British Journal of Industrial Relations 33 (September): 379-415.

Harrison, Alan and Mark Stewart. 1993. "Strike Duration and Strike Size." Canadian Journal of Economics 26 (November): 830-849.

Hauk, William R. and Romain Wacziarg. 2004. "A Monte Carlo Study of Growth Regressions.” NBER Technical Working Paper 296. Cambridge, MA: National Bureau of Economic Research, January.

Hirsch, Barry T. and John T. Addison. 1987. The Economic Analysis of Unions: New Approaches and Evidence. Boston, MA: Allen and Unwin.

Ichniowski, Casey. 1984. "Industrial Relations and Economic Performance: Grievances and Productivity.” National Bureau of Economic Research Working Paper 1367, June. 
Katz, Harry C., Thomas A. Kochan, and Kenneth E. Gobeille. 1983. "Industrial Relations Performance, Economic Performance, and QWL Programs: An Interplant Analysis.” Industrial and Labor Relations Review 37 (October): 3-17.

Kelly, John. 2004. "Social Partnership Agreements in Britain: Labor Cooperation and Compliance.” Industrial Relations 43 (January): 267-292.

Kleiner, Morris M., Jonathan S. Leonard, and Adam Pilarski. 2002 "How Industrial Relations Affect Plant Performance: The Case of Commercial Aircraft Manufacturing.” Industrial and Labor Relations Review 55 (January): 195-2198.

Krueger, Alan B. and Alex Mas. 2004. "Strikes, Scabs and Tread Separations: Labor Strife and the Production of Defective Bridgestone/Firestone Tires.” Journal of Political Economy 112 (April): 253-289.

Lazear, Edward P. 1990. “Job Security Provisions and Employment.” Quarterly Journal of Economics 105 (October): 699-726.

Metcalf, David. 2003. “Unions and Productivity, Financial Performance and Investment.” In International Handbook of Trade Unions, edited by John T. Addison and Claus Schnabel. Cheltenham, England, and Northampton, MA: Edward Elgar, pp.118-171.

Nickell, Stephen J. 1997. "Unemployment and Labor Market Rigidities: Europe versus North America.” Journal of Economic Perspectives 11 (Summer): 55-74.

Nickell, Stephen J. and Richard Layard. 1999. "Labor Market Institutions and Economic performance.” In Handbook of Labor Economics, Vol. 3C, edited by Orley Ashenfelter and David Card. Amsterdam: Elsevier, pp. 3029-3084. 
Nickell.Stephen J. and Jan C. van Ours. 2000. "The Netherlands and the United Kingdom: A European Unemployment Miracle?” Economic Policy 30 (April): 135-180.

Nicoletti, Giuseppe and Stefano Scarpetta. 2001. "Interactions between Product and Labor Market Regulations: Do They Affect Employment?” Paper presented at the Bank of Portugal conference Labor Market Institutions and Economic Outcomes. Cascais, Portugal, June 3.

OECD. 1994. The OECD Jobs Study: Facts, Analysis, Strategies. Paris: Organization for Economic Co-operation and Development.

OECD. 1999. "Employment Protection and Labor Market Performance.” Economic Outlook (June): 49-132.

Scarpetta, Stefano. 1996. “Assessing the Role of Labor Market Policies and Institutional Settings on Unemployment: A Cross-country Study.” OECD Economic Studies 26: 4398.

Soskice, David. 1990. “Wage Determination: The Changing Role of Institutions in Advanced Industrialized Countries.” Oxford Review of Economic Policy 6: 36-61.

Wood, Stephen and Lilian de Menezes. 1998. "High Commitment Management in the U.K.: Evidence from the Workplace Industrial Relations Survey and Employers' Manpower and Skills Practices Survey.” Human Relations 51: 485-515. 
Table 1: Unemployment and Labor Market Institutions (Country Means, 1970-99)

\begin{tabular}{|c|c|c|c|c|c|c|c|c|c|}
\hline & \multirow{3}{*}{$\begin{array}{c}(1) \\
\begin{array}{l}\text { Unemployment } \\
\text { rate }\end{array}\end{array}$} & \multirow{3}{*}{$\begin{array}{c}\text { Replacement } \\
\text { rate }\end{array}$} & \multirow{3}{*}{$\begin{array}{c}(2) \\
\text { Union } \\
\text { coverage }\end{array}$} & \multirow{3}{*}{$\begin{array}{c}\text { (3) } \\
\text { Union density }\end{array}$} & \multirow{3}{*}{$\begin{array}{c}\text { (4) } \\
\text { Tax wedge }\end{array}$} & \multirow{3}{*}{$\begin{array}{c}\text { (5) } \\
\text { Union and } \\
\text { employer } \\
\text { coordination } \\
\end{array}$} & \multirow{3}{*}{$\begin{array}{c}6 \\
\text { Severance } \\
\text { pay }\end{array}$} & \multicolumn{2}{|c|}{$(7)$} \\
\hline & & & & & & & & Qualit & abor relations \\
\hline & & & & & & & & $\begin{array}{c}\text { Strike } \\
\text { rate/volume }\end{array}$ & $\begin{array}{c}\text { Cooperation in } \\
\text { industrial relations }\end{array}$ \\
\hline Australia & 0.067 & 20.7 & 3 & 45.4 & 29 & 1.9 & 1 & 369.4 & 6.2 \\
\hline Austria & 0.029 & 27.7 & 3 & 54.1 & 54.1 & 3 & 2.1 & 5.6 & 7.7 \\
\hline Belgium & 0.082 & 43.0 & 3 & 51.3 & 59.7 & 2 & 0 & 143.1 & 5.9 \\
\hline Denmark & 0.064 & 46.7 & 3 & 69.8 & 62.7 & 2.3 & 0 & 202.4 & 7.9 \\
\hline Finland & 0.068 & 23.0 & 3 & 66.0 & 53.7 & 2 & 0 & 396.1 & 7.4 \\
\hline France & 0.080 & 30.3 & 3 & 16.6 & 54.7 & 2 & 0.9 & 160.6 & 4.4 \\
\hline Germany & 0.058 & 28.7 & 3 & 33.3 & 54.0 & 3 & 0 & 30.0 & 6.7 \\
\hline Ireland & 0.112 & 24.7 & 3 & 53.2 & 52.0 & 2 & 1.4 & 418.9 & 7.3 \\
\hline Italy & 0.092 & 2.0 & 3 & 41.4 & 54.7 & 1.7 & 7.0 & 764.0 & 5.0 \\
\hline Japan & 0.024 & 10.0 & 1 & 30.2 & 24.3 & 3 & 0 & 45.5 & 7.6 \\
\hline The Netherlands & 0.065 & 49.0 & 3 & 33.0 & 56.0 & 2 & 0 & 25.6 & 8.2 \\
\hline New Zealand & 0.043 & 26.7 & 1.8 & 46.8 & 35.0 & 1.3 & 3.3 & 321.6 & 7.1 \\
\hline Norway & 0.032 & 24.3 & 3 & 55.1 & 62.3 & 2.5 & 0 & 75.2 & 7.7 \\
\hline Portugal & 0.059 & 14.3 & 3 & 51.3 & 41.0 & 2 & 7.9 & 97.2 & 6.2 \\
\hline Spain & 0.141 & 24.3 & 3 & 17.5 & 43.0 & 2 & 5.8 & 581.2 & 5.4 \\
\hline Switzerland & 0.013 & 12.0 & 2 & 29.4 & 39.3 & 2 & 0 & 1.3 & 8.6 \\
\hline Sweden & 0.039 & 19.7 & 3 & 78.2 & 60.3 & 2.3 & 0 & 92.4 & 7.8 \\
\hline United Kingdom & 0.070 & 22.3 & 2.7 & 43.8 & 45.3 & 1.3 & 2.5 & 310.8 & 7.0 \\
\hline United States & 0.064 & 12.3 & 1 & 20.4 & 36 & 1 & 0 & 223.6 & 6.6 \\
\hline
\end{tabular}

Sources: The material in columns (1) through (5) is based on the definitions in Appendix Table 1; severance pay in column (6) is based on the Lazear (1990) measure; data on strike volume in column (7) was kindly provided by Claus Schnabel of the University of Erlangen-Nürnberg; and the index of cooperation in industrial relations, also in column (7), was taken from The World Competitiveness Yearbook 2000 (International Institute for Management Development, Switzerland). 
Table 2: Unemployment and the Quality of Labor Relations, Separate Cross-Section Regressions (six 5year periods, 1970-74, 1975-79, 1980-84, 1985-89, 1990-94, and 1995-99).

(Dependent variable: unemployment rate. The quality of labor relations is proxied by the strike rate/volume and by the IMD index of cooperation in industrial relations.)

\begin{tabular}{|c|c|c|c|c|c|c|}
\hline & \multicolumn{6}{|c|}{ Time period } \\
\hline & $1970-74$ & $1975-79$ & 1980-1984 & $1985-89$ & $1990-94$ & 1995-99 \\
\hline Strike rate/volume & $\begin{array}{l}0.00003 \\
(3.90) \\
F(1,16)=15.2\end{array}$ & $\begin{array}{l}0.000026 \\
(2.40) \\
F(1,17)=5.75\end{array}$ & $\begin{array}{l}0.00006 \\
(1.94) \\
F(1,17)=3.76\end{array}$ & $\begin{array}{l}0.0012 \\
(2.23) \\
F(1,17)=4.99\end{array}$ & $\begin{array}{l}0.0003 \\
(6.28) \\
F(1,17)=39.4\end{array}$ & $\begin{array}{l}0.0002 \\
(1.63) \\
F(1,17)=2.66\end{array}$ \\
\hline $\begin{array}{l}\text { Cooperation in } \\
\text { industrial relations }\end{array}$ & $\begin{array}{l}-0.0071 \\
(2.27) \\
F(1,17)=5.13\end{array}$ & $\begin{array}{l}-0.011 \\
(2.45) \\
F(1,17)=6.0\end{array}$ & $\begin{array}{l}-0.0187 \\
(2.63) \\
F(1,17)=6.92\end{array}$ & $\begin{array}{l}-0.0256 \\
(2.94) \\
F(1,17)=8.67\end{array}$ & $\begin{array}{l}-0.019 \\
(2.50) \\
F(1,17)=6.26\end{array}$ & $\begin{array}{l}-0.022 \\
(3.34) \\
F(1,17)=11.16\end{array}$ \\
\hline $\begin{array}{l}\text { Cooperation in } \\
\text { industrial relations } \\
\text { (instrumented) }\end{array}$ & $\begin{array}{l}-0.0172 \\
(2.81) \\
F(1,17)=7.92\end{array}$ & $\begin{array}{l}-0.0213 \\
(2.71) \\
F(1,17)=7.32\end{array}$ & $\begin{array}{l}-0.035 \\
(2.79) \\
F(1,17)=7.79\end{array}$ & $\begin{array}{l}-0.0506 \\
(3.14) \\
F(1,17)=9.86\end{array}$ & $\begin{array}{l}-0.0377 \\
(2.92) \\
F(1,17)=8.52\end{array}$ & $\begin{array}{l}-0.0326 \\
(3.08) \\
F(1,17)=9.49\end{array}$ \\
\hline
\end{tabular}

Absolute t-statistics in parentheses.

Notes: The general model specification is given by $y_{i}=a+b x_{i}+e_{i}$, where the dependent variable, unemployment $\left(y_{i}\right)$, is simply a function of the selected index of the quality of labor relations $\left(x_{i}\right)$. In row 3 the IMD index was instrumented by the observed strike volume in the 70s, 80s, and early 90s. The number of countries in the sample is 19 (18 in 1970-74, row 1). 
Table 3: Unemployment and the Quality of Labor Relations, 1970-99, 5-Year Averages.

(Dependent variable: unemployment rate. The quality of labor relations is proxied by the strike rate/volume and by the IMD index of cooperation in industrial relations.)

\begin{tabular}{|c|c|c|c|c|c|c|c|c|c|}
\hline & \multicolumn{3}{|c|}{ Pooled OLS } & \multicolumn{3}{|c|}{ Random Effects (GLS) } & \multicolumn{3}{|c|}{ Nonlinear least squares (NLS) } \\
\hline & (1) & (2) & (3) & (4) & (5) & (6) & (7) & (8) & (9) \\
\hline Severance pay & $\begin{array}{c}0.0029 \\
(0.0026)\end{array}$ & $\begin{array}{c}0.0018 \\
(0.0013)\end{array}$ & $\begin{array}{c}0.0026 \\
(0.0015)\end{array}$ & $\begin{array}{c}0.0031 \\
(0.0015)\end{array}$ & $\begin{array}{c}0.0019 \\
(0.0015)\end{array}$ & $\begin{array}{c}0.0026 \\
(0.0015)\end{array}$ & $\begin{array}{c}0.0410 \\
(0.0178)\end{array}$ & $\begin{array}{c}0.0173 \\
(0.0158)\end{array}$ & $\begin{array}{c}0.0332 \\
(0.0179)\end{array}$ \\
\hline Replacement rate & $\begin{array}{c}0.0004 \\
(0.0004)\end{array}$ & $\begin{array}{c}0.0008 \\
(0.0004)\end{array}$ & $\begin{array}{c}0.00058 \\
(0.00024)\end{array}$ & $\begin{array}{c}0.0003 \\
(0.0003)\end{array}$ & $\begin{array}{c}0.0007 \\
(0.0003)\end{array}$ & $\begin{array}{c}0.00052 \\
(0.00027)\end{array}$ & $\begin{array}{c}0.0070 \\
(0.0042)\end{array}$ & $\begin{array}{c}0.0138 \\
(0.0039)\end{array}$ & $\begin{array}{c}0.0111 \\
(0.0045)\end{array}$ \\
\hline Union density & $\begin{array}{l}-0.0006 \\
(0.0003)\end{array}$ & $\begin{array}{l}-0.0006 \\
(0.0002)\end{array}$ & $\begin{array}{l}-0.00034 \\
(0.00027)\end{array}$ & $\begin{array}{c}-0.0004 \\
(0.0003)\end{array}$ & $\begin{array}{c}-0.0005 \\
(0.0002)\end{array}$ & $\begin{array}{l}-0.00016 \\
(0.00034)\end{array}$ & $\begin{array}{c}-0.0099 \\
(0.0023)\end{array}$ & $\begin{array}{c}-0.0093 \\
(0.0020)\end{array}$ & $\begin{array}{c}-0.0051 \\
(0.0029)\end{array}$ \\
\hline Union coverage & $\begin{array}{c}0.0176 \\
(0.0059)\end{array}$ & $\begin{array}{c}0.0080 \\
(0.0065)\end{array}$ & $\begin{array}{l}0.0099 \\
(0.0056)\end{array}$ & $\begin{array}{c}0.0156 \\
(0.0074)\end{array}$ & $\begin{array}{c}0.0076 \\
(0.0064)\end{array}$ & $\begin{array}{c}0.0072 \\
(0.0081)\end{array}$ & $\begin{array}{c}0.2790 \\
(0.0922)\end{array}$ & $\begin{array}{c}0.1490 \\
(0.0838)\end{array}$ & $\begin{array}{c}0.1711 \\
(0.1015)\end{array}$ \\
\hline $\begin{array}{l}\text { Union and } \\
\text { employer } \\
\text { coordination }\end{array}$ & $\begin{array}{c}0.0145 \\
(0.0052)\end{array}$ & $\begin{array}{c}0.0015 \\
(0.0068)\end{array}$ & $\begin{array}{c}0.0108 \\
(0.0039)\end{array}$ & $\begin{array}{c}0.0137 \\
(0.0058)\end{array}$ & $\begin{array}{c}0.0018 \\
(0.0061)\end{array}$ & $\begin{array}{c}0.0092 \\
(0.0054)\end{array}$ & $\begin{array}{c}0.2168 \\
(0.0818)\end{array}$ & $\begin{array}{c}0.0212 \\
(0.0781)\end{array}$ & $\begin{array}{c}0.1668 \\
(0.0051)\end{array}$ \\
\hline Tax wedge & $\begin{array}{l}0.000006 \\
(0.0003)\end{array}$ & $\begin{array}{l}0.00008 \\
(0.0003)\end{array}$ & $\begin{array}{c}0.00002 \\
(0.00021)\end{array}$ & $\begin{array}{l}0.00005 \\
(0.0004)\end{array}$ & $\begin{array}{c}0.0001 \\
(0.0003)\end{array}$ & $\begin{array}{c}0.0001 \\
(0.0003)\end{array}$ & $\begin{array}{l}-0.00009 \\
(0.00509)\end{array}$ & $\begin{array}{c}0.0002 \\
(0.0044)\end{array}$ & $\begin{array}{l}-0.0013 \\
(0.0051)\end{array}$ \\
\hline $\begin{array}{l}\text { Strike rate } \\
\text { (over time average) }\end{array}$ & & $\begin{array}{c}0.00009 \\
(0.00003)\end{array}$ & & & $\begin{array}{c}0.00009 \\
(0.00003)\end{array}$ & & & $\begin{array}{c}0.0014 \\
(0.0003)\end{array}$ & \\
\hline $\begin{array}{l}\text { Cooperation in } \\
\text { Industrial relations }\end{array}$ & & & $\begin{array}{l}-0.0093 \\
(0.0036)\end{array}$ & & & $\begin{array}{l}-0.0116 \\
(0.0050)\end{array}$ & & & $\begin{array}{l}-0.1616 \\
(0.0620)\end{array}$ \\
\hline $\mathrm{R}^{2}$ & 0.56 & 0.66 & 0.59 & 0.55 & 0.66 & 0.58 & 0.60 & 0.72 & 0.63 \\
\hline Wald $\chi^{2}$ & & & & 106.5 & 121.05 & 134.38 & & & \\
\hline $\mathrm{F}$ & 14.95 & 41.0 & 13.37 & & & & 10.74 & 16.85 & 11.25 \\
\hline $\mathrm{N}$ & 92 & 92 & 92 & 92 & 92 & 92 & 92 & 92 & 92 \\
\hline
\end{tabular}

Robust standard errors in parentheses.

Notes: The general specification of the model in columns (1)-(6) is given by equation (1) in the text, while in columns (7)-(9) it is given by equation (2). Sources and definitions of labor market institutions are given in Appendix Table 1. The sample period contains six 5-year data points, ranging from 1970-74 to 1995-99, and (a maximum of) nineteen countries (unbalanced panel). 
Table 4: Unemployment and the Quality of Labor Relations, 1970-99, 5-year Averages. (Dependent variable: unemployment rate. The quality of labor relations is proxied by the strike rate/volume.)

\begin{tabular}{|l|c|c|c|}
\hline & Pooled OLS & Random Effects (GLS) & Nonlinear Least Squares (NLS) \\
\cline { 2 - 4 } & $(1)$ & $(2)$ & $(3)$ \\
\hline \multirow{3}{*}{ Severance pay } & 0.0030 & 0.0035 & 0.0335 \\
& $(0.0024)$ & $(0.0017)$ & $(0.0177)$ \\
Replacement rate & 0.0005 & 0.0004 & 0.0071 \\
& $(0.0004)$ & $(0.0003)$ & $(0.0041)$ \\
Union density & -0.0006 & -0.0005 & -0.0010 \\
& $(0.0003)$ & $(0.0002)$ & $(0.0022)$ \\
Union coverage & 0.0134 & 0.0152 & 0.2269 \\
& $(0.0055)$ & $(0.0063)$ & $(0.0941)$ \\
Union and employer & 0.0106 & 0.0133 & 0.1615 \\
coordination & $(0.0054)$ & $(0.0057)$ & $(0.8249)$ \\
\hline & & & 0.0018 \\
Tax wedge & 0.0001 & 0.00009 & $(0.0051)$ \\
\hline Strike rate & $(0.0002)$ & $0.0003)$ & 0.0005 \\
& 0.000019 & 0.0000003 & $(0.0002)$ \\
\hline $\mathrm{R}^{2}$ & $(0.000011)$ & $(0.00001)$ & 0.61 \\
\hline Wald $\chi^{2}$ & 0.57 & 0.55 & 10.20 \\
\hline $\mathrm{F}$ & & 109.3 & 91 \\
\hline $\mathrm{N}$ & 21.23 & 91 & \\
\hline
\end{tabular}

Robust standard errors in parenthesis.

Notes: See Notes to Table 3. 
Table 5: Unemployment and the Quality of Labor Relations, 1970-99, 5-year Averages, Fixed Effects, Nonlinear Least Squares with Country Dummies, and Between Effects Estimation.

(Dependent variable: unemployment rate. The quality of labor relations is proxied by the strike rate/volume.)

\begin{tabular}{|c|c|c|c|}
\hline & Fixed Effects (FE) & Nonlinear Least Squares (NLS) & Between Effects (BE) \\
\hline & (1) & (2) & (3) \\
\hline Severance pay & $\begin{array}{c}-0.00018 \\
(0.0038)\end{array}$ & $\begin{array}{c}0.1628 \\
(0.0640)\end{array}$ & $\begin{array}{c}0.0017 \\
(0.0018)\end{array}$ \\
\hline Replacement rate & $\begin{array}{c}0.0004 \\
(0.0004)\end{array}$ & $\begin{array}{c}0.0287 \\
(0.0086)\end{array}$ & $\begin{array}{c}0.0011 \\
(0.00047)\end{array}$ \\
\hline Union density & $\begin{array}{c}0.0006 \\
(0.0005)\end{array}$ & $\begin{array}{c}0.0004 \\
(0.0057)\end{array}$ & $\begin{array}{c}-0.00059 \\
(0.00026)\end{array}$ \\
\hline Union coverage & $\begin{array}{c}0.0118 \\
(0.0126)\end{array}$ & $\begin{array}{c}0.3053 \\
(0.2313)\end{array}$ & $\begin{array}{c}0.0059 \\
(0.0104)\end{array}$ \\
\hline $\begin{array}{l}\text { Union and employer } \\
\text { coordination }\end{array}$ & $\begin{array}{c}0.0181 \\
(0.0116)\end{array}$ & $\begin{array}{c}0.2552 \\
(0.2026)\end{array}$ & $\begin{array}{l}-0.00081 \\
(0.0096)\end{array}$ \\
\hline Tax wedge & $\begin{array}{c}0.0017 \\
(0.0010)\end{array}$ & $\begin{array}{c}-0.0147 \\
(0.0113)\end{array}$ & $\begin{array}{c}0.000009 \\
(0.00056)\end{array}$ \\
\hline Strike rate & $\begin{array}{c}-0.00004 \\
(0.000019)\end{array}$ & $\begin{array}{l}-0.0014 \\
(0.0004)\end{array}$ & $\begin{array}{c}0.000104 \\
(0.0000281)\end{array}$ \\
\hline $\mathrm{R}^{2}$ & 0.62 & 0.86 & 0.85 \\
\hline $\bar{F}$ & 7.53 & 14.16 & 6.43 \\
\hline $\mathrm{N}$ & 91 & 91 & 19 \\
\hline
\end{tabular}

Robust standard errors in parentheses.

Notes: The general specification of the model in column (1) is given by equation (1) in the text, while in column (2) it is given by equation (2), with country dummies added to the specification. Column (3) presents the between effects estimation. Sources and definitions of labor market institutions are given in Appendix Table 1. The sample period comprises six 5-year data points, from 1970-74 to 1995-99, and (a maximum of) nineteen countries (unbalanced panel). 
Appendix Table 1: Description of Institutional Variables

\begin{tabular}{|c|c|c|c|c|}
\hline \multicolumn{2}{|l|}{ Variable/source } & \multirow{2}{*}{\begin{tabular}{l}
\multicolumn{1}{c}{ Definition/range } \\
$\begin{array}{l}\text { Ranking of employment protection legislation by "strictness". It is } \\
\text { an average country ranking based on four different indicators, } \\
\text { where } 1 \text { denotes the least rigidity. }\end{array}$ \\
\end{tabular}} & \multirow{2}{*}{$\begin{array}{l}\text { Raw year/period } \\
1985-93\end{array}$} & \multirow{2}{*}{\begin{tabular}{|l|} 
Interpolated periods \\
1970-99, five-year periods.
\end{tabular}} \\
\hline Employment protection $(E P L)$ & $\begin{array}{l}\text { Fixed measure (OECD, 1994, } \\
\text { Table 6.7). }\end{array}$ & & & \\
\hline \multirow{4}{*}{$\begin{array}{l}\text { Replacement rate (unemployment } \\
\text { insurance replacement rate) (UIRR) }\end{array}$} & \multirow{3}{*}{$\begin{array}{l}\text { Time-varying (OECD, 1994, Table } \\
\text { 8.B.1). }\end{array}$} & \multirow[t]{3}{*}{ Summary measure of benefit entitlements on a gross basis. } & 1971 & 1970-74; 1975-79 \\
\hline & & & 1981 & 1980-84; 1985-89 \\
\hline & & & 1991 & 1990-94; 1995-99 \\
\hline & $\begin{array}{l}\text { Fixed measure }(*) \\
\text { (Blanchard and Wolfers, 2000). }\end{array}$ & Share of past earnings replaced by unemployment benefits. & 1983-88 and 1989-94 & 1970-99, five-year periods. \\
\hline \multirow[t]{5}{*}{ Union density (UDEN) } & \multirow{4}{*}{$\begin{array}{l}\text { Time-varying measure (OECD, } \\
\text { 1997, Table 3.3). }\end{array}$} & \multirow[t]{4}{*}{ Trade union density. } & 1970 & 1970-74; 1975-79 \\
\hline & & & 1980 & 1980-84; 1985-89 \\
\hline & & & 1990 & $1990-94$ \\
\hline & & & 1994 & $1995-99$ \\
\hline & $\begin{array}{l}\text { Fixed measure }\left(^{*}\right) \\
\text { (Blanchard and Wolfers, } 2000 .\end{array}$ & Trade union density. & 1983-88 and 1989-94 & 1970-99, five-year periods. \\
\hline \multirow[t]{4}{*}{ Union coverage (UCOV) } & \multirow[t]{2}{*}{$\begin{array}{l}\text { Time-varying measure (OECD, } \\
\text { 1997, Table 3.3). }\end{array}$} & \multirow{4}{*}{$\begin{array}{l}\text { Share of workers covered by union bargaining: } 1 \text { denotes less than } \\
25 \text { percent; } 2 \text { means from } 25 \text { to } 75 \text { percent; and } 3 \text { indicates over } 70 \\
\text { percent. }\end{array}$} & 1980 & $\begin{array}{l}\text { 1970-74; 1975-79; 1980-84; } \\
1985-89\end{array}$ \\
\hline & & & 1990 & $1990-94$ \\
\hline & \multirow{2}{*}{$\begin{array}{l}\text { Fixed measure }\left(^{*}\right) \\
\text { (Blanchard and Wolfers, } 2000 .\end{array}$} & & 1994 & $1995-99$ \\
\hline & & & $1983-88$ and $1989-94$ & 1970-99, five-year periods. \\
\hline \multirow[t]{4}{*}{$\begin{array}{l}\text { Union and employer coordination } \\
(T C O O R)\end{array}$} & \multirow[t]{3}{*}{$\begin{array}{l}\text { Time-varying measure (OECD, } \\
\text { 1997, Table 3.3). }\end{array}$} & \multirow{3}{*}{$\begin{array}{l}\text { Employer and union_coordination in bargaining. It is assigned a } \\
\text { value of } 1 \text { if there is no economy-wide coordination/centralization } \\
\text { up to } 3 \text { if the degree of coordination/centralization is very high. }\end{array}$} & 1980 & $\begin{array}{l}\text { 1970-74; 1975-79; 1980-84; } \\
1985-89\end{array}$ \\
\hline & & & 1990 & $1990-94$ \\
\hline & & & 1994 & 1995-99 \\
\hline & $\begin{array}{l}\text { Fixed measure }(*) \\
\text { (Blanchard and Wolfers, } 2000 .\end{array}$ & $\begin{array}{l}\text { Employer and employee coordination in bargaining. It is coded } \\
\text { between } 2 \text { and } 6 \text { in ascending order (the sum of employer and } \\
\text { employee coordination). }\end{array}$ & 1983-88 and 1989-94 & 1970-99, five-year periods. \\
\hline \multirow[t]{4}{*}{ Tax wedge (TXWEDGE) } & \multirow{3}{*}{$\begin{array}{l}\text { Time-varying measure (OECD, } \\
\text { 1997, Table 25). }\end{array}$} & \multirow{3}{*}{$\begin{array}{l}\text { Overall tax wedge (in percentage of average production worker } \\
\text { earnings). }\end{array}$} & 1978 & 1970-74; 1975-79 \\
\hline & & & 1985 & $1980-84 ; 1985-89$ \\
\hline & & & 1994 & $\begin{array}{l}1990-94 ; 1995-99 \\
\end{array}$ \\
\hline & $\begin{array}{l}\text { Fixed measure }\left(^{*}\right) \\
\text { (Blanchard and Wolfers, } 2000 .\end{array}$ & $\begin{array}{l}\text { Tax burden. It is measured as the sum of the average payroll, } \\
\text { income, and consumption tax rates. }\end{array}$ & 1983-88 and 1989-94 & 1970-99, five-year periods. \\
\hline
\end{tabular}

Notes: The data on the fixed measures denoted by * was downloaded from http://www.mit.edu/blanchar/www.articles.html. Blanchard and Wolfers (2000) take a simple average of Nickell’s (1997) original data over two periods, 1983-88 and 1989-94. Time-varying measures based on authors' own calculations. 
Figure 1: Strike Rate/Volume in the Sample of OECD Countries

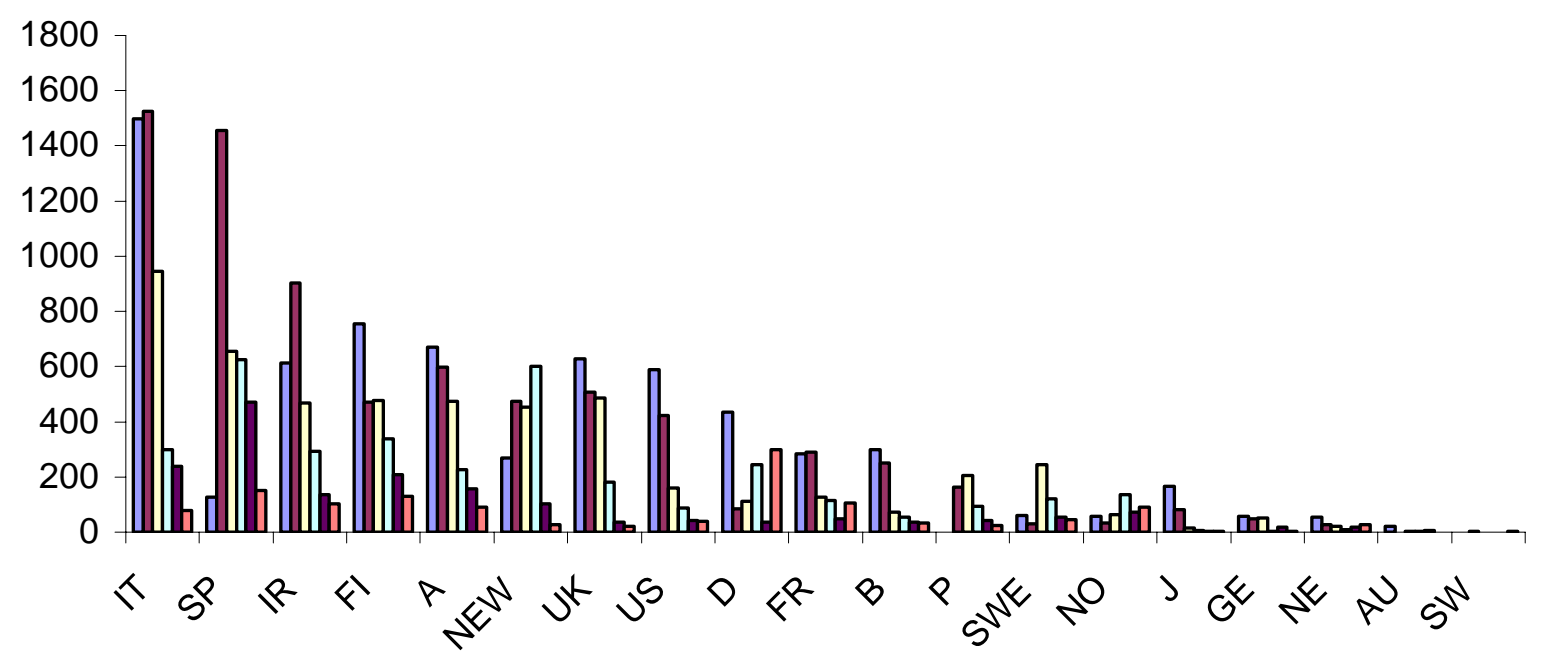

Notes: Strike rate/volume is given by the ratio of days not worked per thousand paid employees. The raw annual data on strikes is based on a revised version of the ILO series (Yearbook of Labor Statistics, Tables 9A-D), kindly made available by Claus Schnabel. The height of each column gives the average strike rate over five years for each of the six 5-year periods in the sample, beginning with 1970-74 and ending with 1995-99. 